\title{
Impact of the Migration Outflow of the Young Population on the Economic Security of the Region
}

\author{
Irina I. Chueva 1[ORCID 0000-0002-6053-5045], \\ Elina V. Polyanskaya 2[ORCID 0000-0002-6741-9979], \\ Lilia H. Kolmakova 2*[ORCID 0000-0001-7584-5153], \\ Yury V. Daneykin 3[ORCID 0000-0001-7181-2557]
}

\author{
${ }^{1}$ LEONOV Moscow Region University of Technology, Korolev, Russia \\ ${ }^{2}$ Astrakhan State University, Astrakhan, Russia \\ ${ }^{3}$ Yaroslav-the-Wise Novgorod State University, Veliky Novgorod, Russia \\ erembetoval@mail.ru
}

\begin{abstract}
In the 21st century, the study of migration processes is becoming an area of increased attention and intersection of scientific interests of economists and sociologists. Migration issues are acquiring a special role for Russia, since in modern conditions of economic development, there is a tendency for an outflow of labor resources from the regions to large administrative centers and metropolises. The main reasons for migration: economic, political and cultural-religious. Educational migration of young people may negatively affect regional labor markets in the future. The migration of the young population depends on traditional factors, within the region and between the constituent entities of the Russian Federation, as well as on specific factors that influence decision-making on the choice of place of residence. The outflow of the economically active part of the population from the "depressed" territories negatively affects the quality of management and the quality of human capital. The migration outflow of the young population against the background of depopulation has an impact on the socioeconomic state and development of the regions. In Russia, a migration policy has been developed, which should contribute to solving global problems in the field of economic and social development of the country, as well as to ensure economic security and protection of national interests. Aspects of the impact of migration processes on the economic potential are comprehensively considered by both foreign and domestic economists. The article is devoted to assessing the impact of the migration outflow of the young population on the main socio-economic indicators and economic security of the region. The statistical data of the Astrakhan region were analyzed, on the basis of which a correlation analysis was carried out, according to the results of which the regularity of the influence of the outflow of young personnel on the innovative component of the regional economy was revealed.
\end{abstract}

Keywords: economic security of the region, migration, innovative development of the region

\section{INTRODUCTION}

In recent years, in the constituent entities of the Russian Federation, there has been an active increase in the migration outflow of the population to large cities and megalopolises, including the young population, which cannot but affect the economic security of the country and at the regional level as a whole.

Considering the "Strategy of the Economic Security of the Russian Federation for the Period up to 2030 " [1], it can be noted that economic security is a kind of state of protection of the national economy from external and internal threats, in which the following are ensured: the economic sovereignty of the country, the unity of its economic space, conditions for the implementation of Russia's strategic national priorities.

When determining the level of economic security, it is necessary to rely on the use of various indicators and ratios with their threshold values. To date, foreign and domestic authors have developed 
numerous methods for assessing economic security at the macro and micro levels, a number of groups of indicators for certain areas of the economy.

The official list of indicators of the economic security of the Russian Federation according to the Decree of the President of the Russian Federation [1] includes 40 items, among which there are no indicators characterizing migration processes. There is no generally accepted and approved methodology for assessing economic security and a system of indicators for a region.

The studies of foreign and domestic economists are devoted to the influence of migration processes on the economic potential. Foreign works are presented by the following authors: V. Bovea, L. Elia [2], T. Walmsley [3], S. Sassen [4], P. Wiraszka, U. Karpinska [5], etc. The analysis of migration processes at the regional level and their impact on economic security is presented in the works of Russian researchers L.N. Lipatova and authors [6], V.A. Passage [7], N.A. Pruel [8], I.P. Tsapenko [9], E.A. Edinak [10] and others.

At the federal level, the main tasks within the framework of ensuring economic security are implemented in such areas as the security of economic entities, foreign economic, scientific and technical, food, social, demographic security. Currently, issues in the field of migration outflow of the population are not reflected in regulatory legal acts and strategic planning documents $[11,12]$. The problem of the migration outflow of youth from regional centers as a threat to the economic security of the region has not been sufficiently studied to date.

\section{MATERIALS AND METHODS}

The aim of the study is to study the impact of one of the aspects of migration (the outflow of young people under the age of 39) on the economic security of the region (using the example of the Astrakhan region). For this, statistical data were analyzed, on the basis of which a correlation analysis of socio-economic indicators of the region with a negative development trend was carried out.

The information base of the study was foreign and Russian publications in the field of economic security and migration processes.

The study used: analysis and synthesis, theoretical observation, dialectical logic, systematization, generalization, scientific hypothesis, scientific evidence, as well as correlation analysis by the Pearson method [13].

\section{RESULTS}

According to RIA "Rating", the standard of living of the Astrakhan region is steadily declining - 58th place in 2020 (in $2019-54^{\text {th }}$ place) [14]. The permanent decline in the standard of living in all constituent entities of the Russian Federation is confirmed by a study conducted in 2021 by the RIA Novosti agency [15] - in the rating of Russian regions in terms of unemployment in the third quarter of 2020, the Astrakhan region is in 69th place.

According to the Federal State Statistics Service, the unemployment rate in the Astrakhan region was the highest in 2019 compared to other nearby regions of the Russian Federation. The structure of the number of unemployed in different age groups in 2019 in a regional context is reflected in (Figure 1). The main age groups of the unemployed are the population aged 20 to 59 .

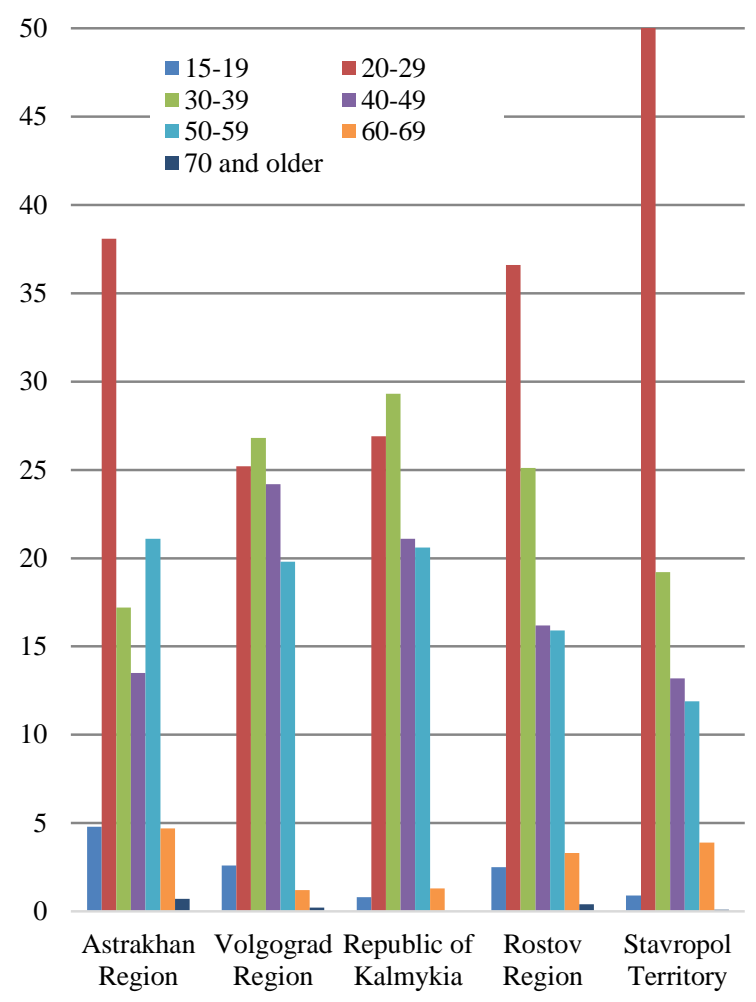

Figure 1. Structure of unemployed by age group in 2019 (15 years and older), \%

Source: [16]

The unemployment rate for the age categories under consideration in the constituent entities of the Russian Federation is also high. In the Astrakhan region, the highest unemployment rate is noted among the youngsters (15-19 years old) $-61.4 \%$, persons aged 20-29 years old $-14.3 \%$ and the working-age population as a whole $-7.5 \%$, which 
significantly exceeds the average Russian level, and is also ahead of similar indicators in other constituent entities of the Russian Federation.

Thus, a low standard of living, a significant level of unemployment among the population under the age of 39 and the able-bodied population leads to the departure of young, able-bodied personnel from the region.
Analyzing the migration process in the Astrakhan region in 2017-2019, one can talk about a high proportion of the working-age population from 16 to 59 years old $(75 \%)$, among which the proportion of the population aged 18 to 39 years is about $57 \%$ (Table 1). The considered indicators for the Astrakhan region have the highest values among the selected group of constituent entities of Russia.

Table 1. The structure of migrants by regions of the Russian Federation for 2017-2019 (\%)

\begin{tabular}{|c|c|c|c|c|c|}
\hline Year & Astrakhan Region & Volgograd Region & Rostov Region & Stavropol Territory & Republic of Kalmykia \\
\hline \multicolumn{6}{|c|}{ Working age migrants (\%) } \\
\hline 2017 & 73.8 & 70.4 & 72.2 & 71.8 & 68.8 \\
\hline 2018 & 75.2 & 70.6 & 71.2 & 70.1 & 68.4 \\
\hline 2019 & 74.8 & 70,7 & 69.9 & 68.2 & 67.6 \\
\hline \multicolumn{6}{|c|}{ Migrants aged 18-39 (\%) } \\
\hline 2017 & 56.0 & 50.9 & 53.1 & 53.0 & 49.8 \\
\hline 2018 & 57.6 & 21.0 & 51.8 & 51.0 & 48.6 \\
\hline 2019 & 57.7 & 50.6 & 51.0 & 49.6 & 46.3 \\
\hline
\end{tabular}

Source: Compiled by the authors

Another feature of migration from the Astrakhan region is the tendency towards an increase in the number of people who left due to international migration flows (2017-2019):

- for all ages - an increase by $18.3 \%$;

- people of working age - by $21.3 \%$;

- persons aged $18-39$ - by $26.0 \%$;

- youth aged $14-35$ - by $23.1 \%$.

Thus, prevailing in the Astrakhan region is the outflow of the working-age population, the largest part of which is people from 18 to 39 years old. Based on the data presented, we tried to answer the question: what impact does the migration of the population under the age of 39 have on the region's economy and ensuring economic security?

The Federal State Statistics Service monitors the number of young people under the age of 39 (inclusive) who have a PhD degree. Young scientists are a social and professional group that is distinguished within the scientific community as persons in the age range from 18 to 39 . A similar division is used by the International Association of Young Scientists "The World Association of Young Scientists", where the age limit is 40 years [17].

Within the framework of this article, we analyzed the migration outflow from the region of persons in this age interval, using the example of the Astrakhan region and nearby constituent entities of Russia.

Based on the analysis of data by the Federal State Statistics Service, in the Astrakhan region in 2013-2019 there was a trend towards a decrease in the proportion of researchers under the age of 39 (based on the total number of researchers), and a decrease in the coefficient of inventive activity (the number of Russian patent applications for inventions filed in Russia per 10 thousand of population) (Figure 2). When comparing the data on the number of people of 18 to 39 years old who left the region with the level of the share of researchers under the age of 39 in the total number of researchers, it can be stated that its decline is taking place against the background of a positive migration trend.

As follows from Figure 3, in 2018 the highest value of the migration outflow was accompanied by the maximum decrease in the share of researchers under the age of 39 in the total number of researchers.

A similar picture is observed when comparing migration data with the coefficient of inventive activity (Figure 4).

Thus, it can be assumed that an increase in the outflow of population from the region can negatively affect labor potential; migration leads to a loss of human capital, to a reduction in the scientific (intellectual), innovative potential of the region, which, as a result, can become a threat to economic security.

One of the priority indicators of the development of a constituent entity of Russia is the share of products of high-tech and science-intensive industries in the GRP. The criterion for high-tech industries is a high level of technological development, determined in relation to the cost of research and development (R\&D) to GRP (Figure 5). 


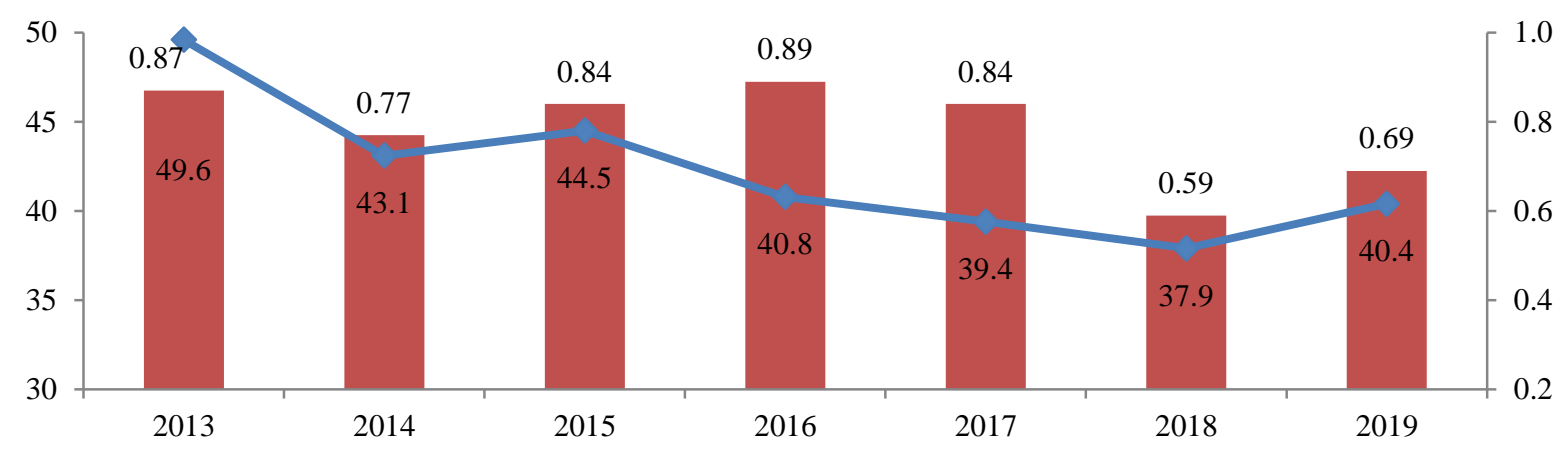

Coefficient of inventive activity $\longrightarrow$ Share of researchers under the age of 39 in the total number of researchers

Figure 2. Share of researchers under the age of 39 in the total number of researchers, coefficient of inventive activity in the Astrakhan region, 2013-2019

Source: Compiled by the authors

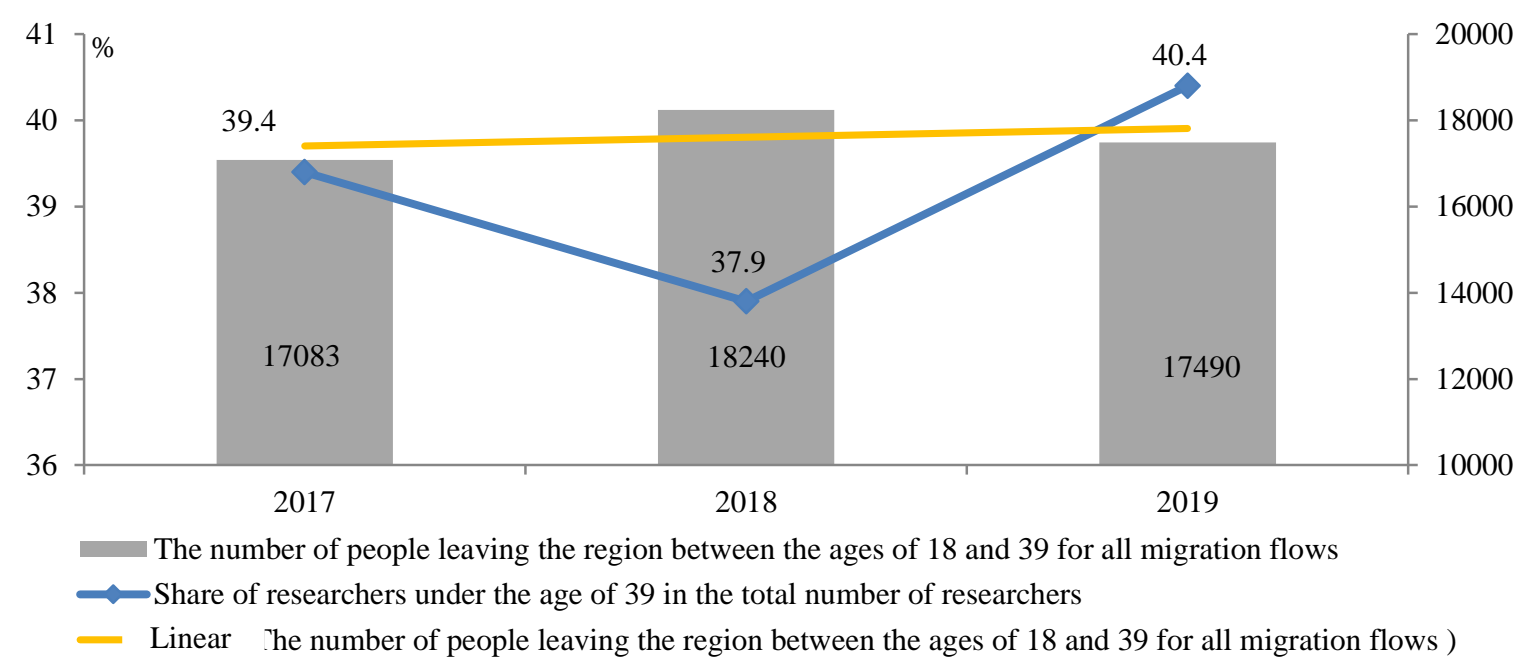

Figure 3. Dynamics of the number of people aged 18 to 39 who left the region for all migration flows, indicators of the share of researchers under the age of 39 in the total number of researchers in the Astrakhan region, 2017-2019 Source: Compiled by the authors

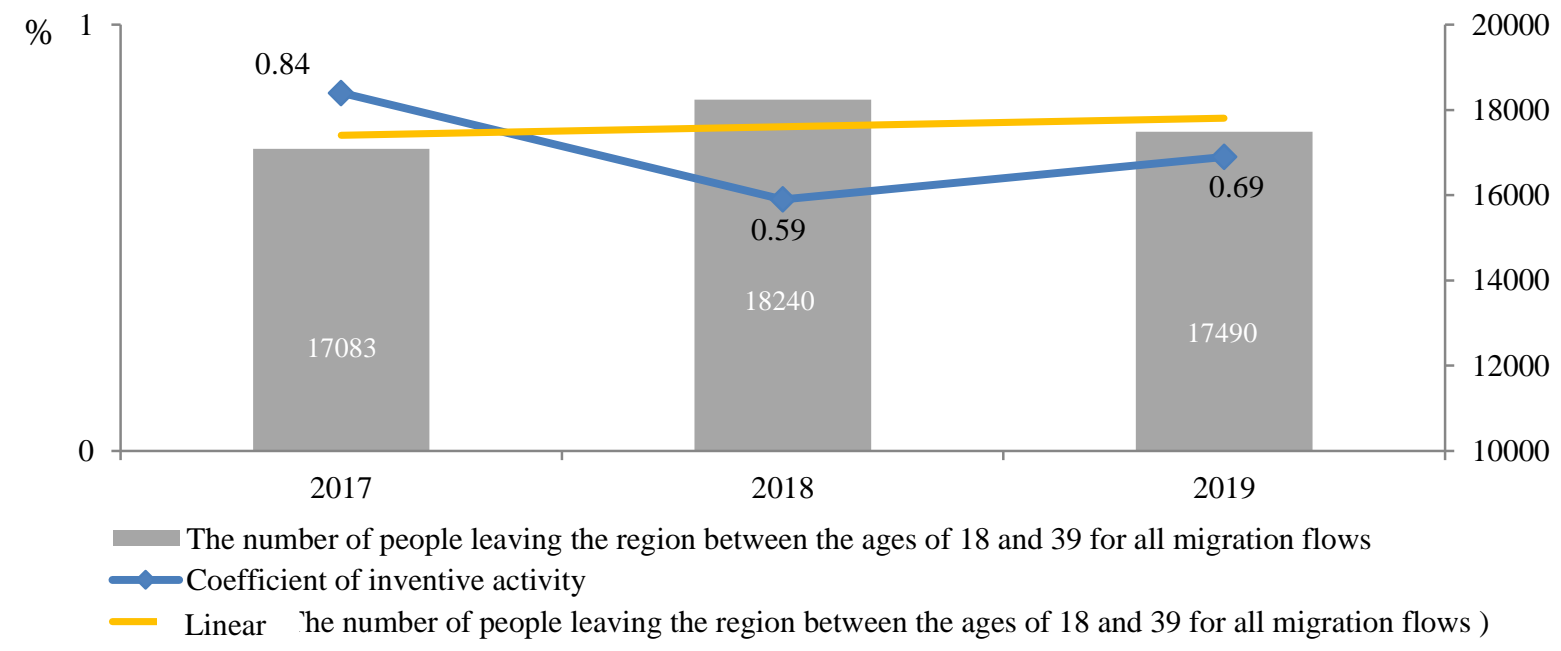

Figure 4. Dynamics of the number of people who left the region at the age of 18 to 39 by all migration flows and the coefficient of inventive activity in the Astrakhan region, 2017-2019

Source: Compiled by the authors 
According to Figure 5, it can be seen that in the Astrakhan region the share of high-tech and knowledge-intensive industries in GRP has the lowest value among the regions under consideration, a negative trend is observed over a four-year period, which is associated with the outflow of highly qualified personnel (Figure 6). The graph shows that with an increase or decrease in the number of people leaving the region at the age of 18 to 39 , the opposite change in the share of products of high-tech and knowledge-intensive industries in the GRP occurs.

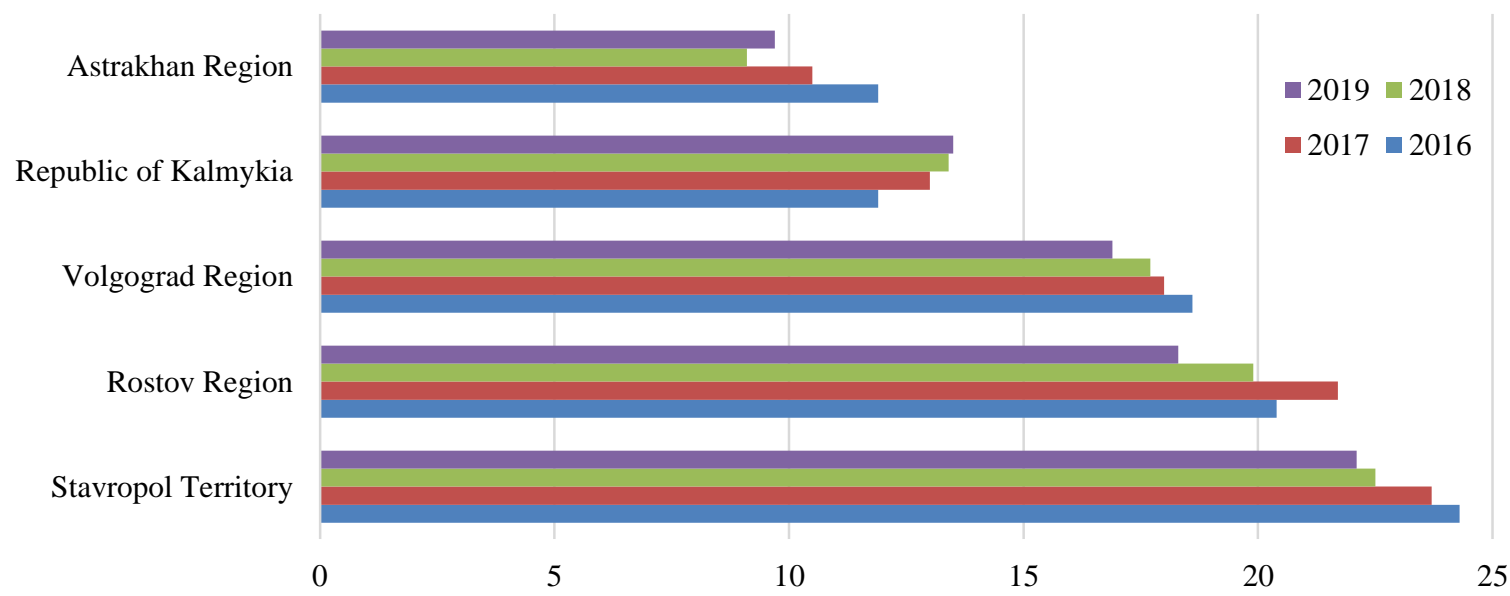

Figure 5. Share of products of high-tech and knowledge-intensive industries in GRP, 2016-2019 (\%) Source: Compiled by the authors

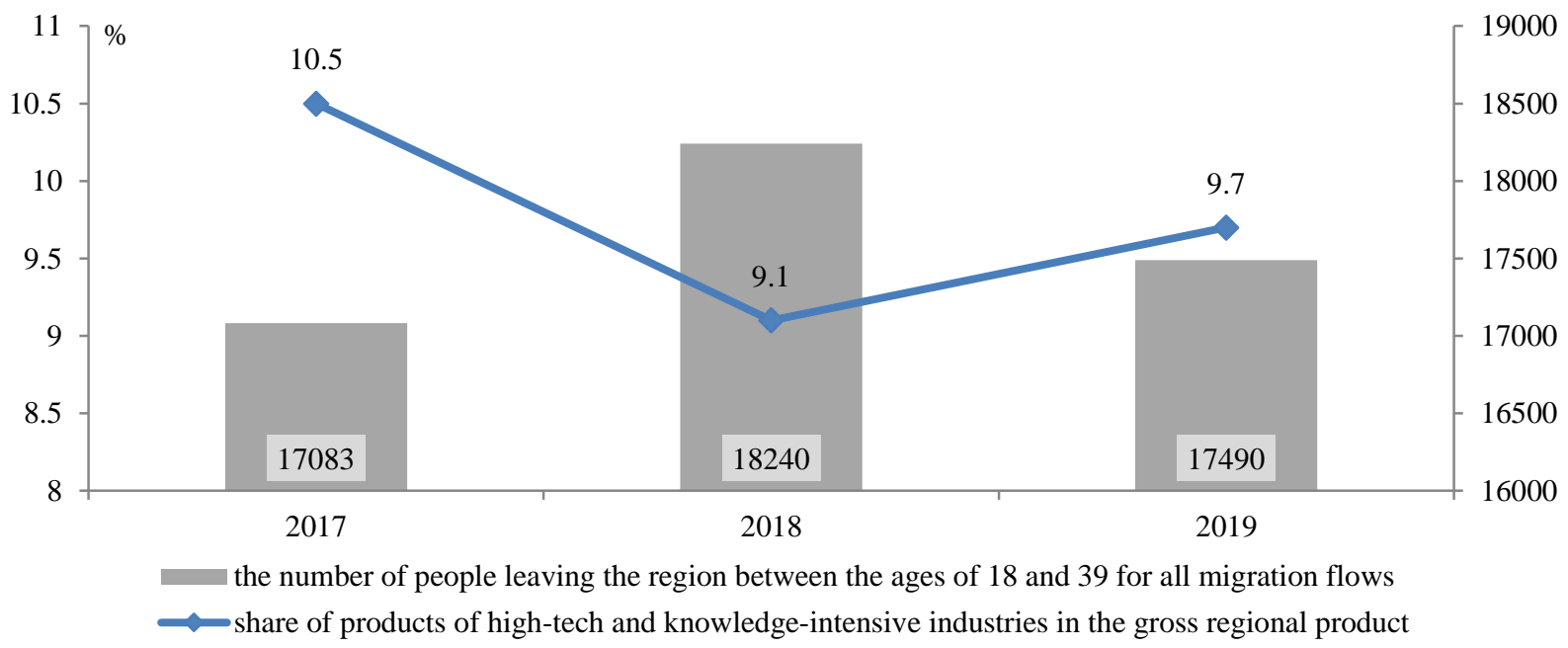

Figure 6. Dynamics of the number of people leaving the region aged 18 to 39 for all migration flows and the share of products of high-tech and knowledge-intensive industries in the GRP in the Astrakhan region, 2017-2019 Source: Compiled by the authors

Accumulating the intermediate results of the analysis, one can conclude that there is a relationship between an increase in the outflow of the population from the region between the ages of 20 and 39 with the indicators of a decrease in the share of researchers under the age of 39 in the total number of researchers, the coefficient of inventive activity and the share of products of high-tech and scienceintensive industries in GRP.

When analyzing statistical indicators, a positive trend and dependence of an increase in the outflow of the population aged 18 to 39 from the region and a decrease in the ratio of the volume of investments in fixed assets to GRP, the index of the physical volume of investments in fixed assets, were revealed. An illustrative analysis is presented in (Figure 7).

It should be noted that the "Share of investments in fixed assets in GDP" is one of the indicators of the state of the country's economic security [1], in this regard, the impact of this indicator on the development of the economy and ensuring the 
economic security of the region should not be underestimated. Also, in accordance with the "Strategy for the Economic Security of the Russian Federation for the Period up to 2030", one of the main conditions entailing a threat to economic security is insufficient investment in the real sector of the economy, due to an unfavorable investment climate.

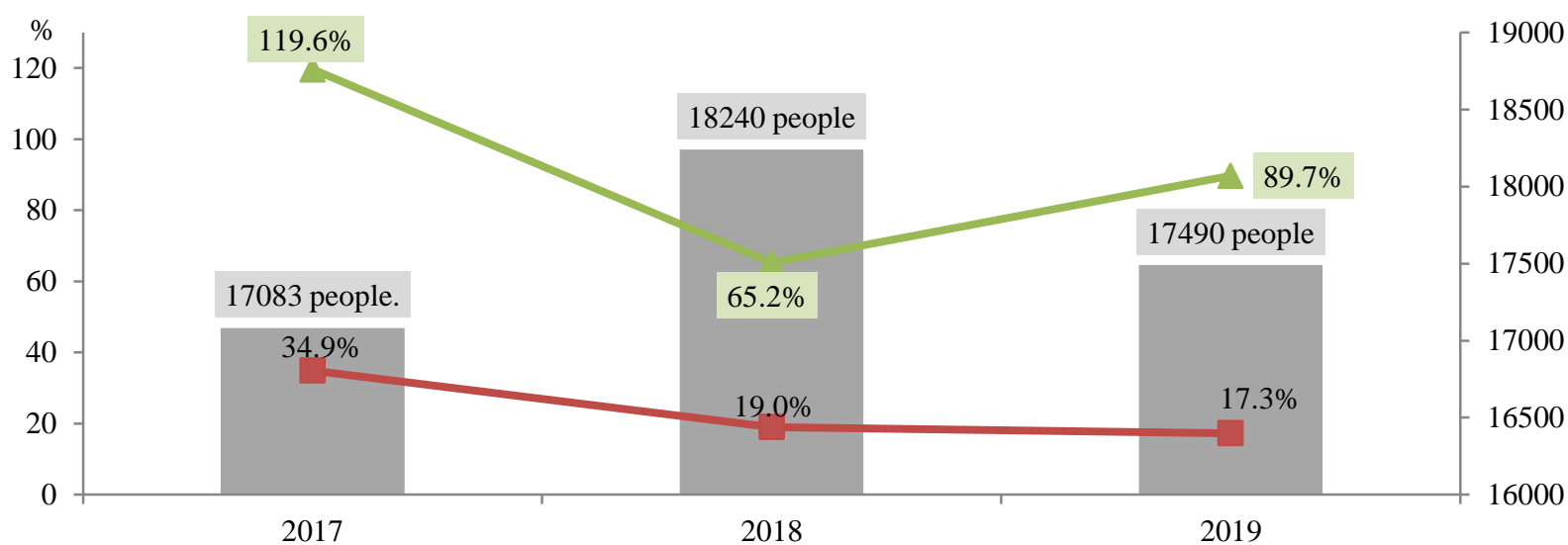

the number of people leaving the region between the ages of 18 and 39 for all migration flows
the ratio of the volume of investments in fixed assets to GRP
index of physical volume of investments in fixed assets

Figure 7. The number of people leaving the region aged 18 to 39 for all migration flows, the ratio of the volume of investments in fixed assets to GRP, the index of the physical volume of investments in fixed assets in the Astrakhan region, 2017-2019

Source: Compiled by the authors

The graph shows that the maximum value of the number of people who left the region aged 18 to 39 (18.2 thousand people, an increase by $6.8 \%$ ) in 2018 corresponds to the minimum value of the index of physical volume of investments in fixed assets $65.2 \%$, (decrease twofold), as well as a decrease in the value of the ratio of the volume of investments in fixed assets to GRP by 15.9 percentage points $(19.0 \%)$. Also in 2019 , with a decrease in migration outflow by $4.1 \%$, an increase in the index of physical volume of investments in fixed assets to $89.7 \%$ was recorded, a decrease in the ratio of investments in fixed assets to GRP by 1.7 percentage points $(17.3 \%)$.

The reduction in investment is a consequence of the reduction in demand for goods and services under the influence of minor fluctuations in consumption. According to the Federal State Statistics Service, in the GRP structure, the share of expenditures on actual final consumption of households in 2015-2018 was constantly declining from $78.2 \%$ to $47.1 \%$. The growth rates of expenses were not high; in 2016, expenses decreased by $4.3 \%$. In the structure of consumer spending, expenses on payment for services have been declining annually since 2017 (17.6\%, 17.5\%, 17.4\%), this is confirmed by the low growth rates of the regional index of the physical volume of retail trade turnover and the volume of paid services to the population (Figure 8).

As can be seen from the graph, an increase in the outflow of the population from the region in 2018 by $6.8 \%$ (18240 people) is accompanied by a decrease in the index of the physical volume of GRP by 7.4 percentage points $(104.9 \%)$, a slight increase in the index of physical retail trade turnover $(101.5 \%)$ and the physical volume of paid services to the population $(100.1 \%)$.

To clarify the impact of the outflow of the population aged 18 to 39 on the indicators of the socio-economic development of the region, a correlation analysis was carried out using the Pearson method to determine the relationship between two different values for the period of 2017 2019 (Table 2).

Using this statistical method, the limits of the possible relationship between the two variables were determined. The correlation coefficient ranges from -1 to 1 .

According to the results of the correlation analysis, the following interconnections of indicators have a negative correlation:

1) an increase in the number of people leaving the region between the ages of 18 and 39 affects the decrease in the coefficient of inventive activity; 
2) an increase in the number of people leaving the region between the ages of 18 and 39 affects the decrease in the ratio of the volume of investments in fixed assets to the GRP;

3) an increase in the number of people leaving the region between the ages of 18 and 39 affects the decrease in the share of high-tech and science-intensive industries in the GRP;

4) an increase in the number of those who left the region at the age of 18 to 39 affects the decrease in the share of researchers under the age of 39 in the total number of researchers;

5) an increase in the number of people leaving the region between the ages of 18 and 39 affects the decrease in the index of the physical volume of investments in fixed assets;

6) an increase in the number of people leaving the region between the ages of 18 and 39 affects the decrease in the index of the physical volume of the GRP.

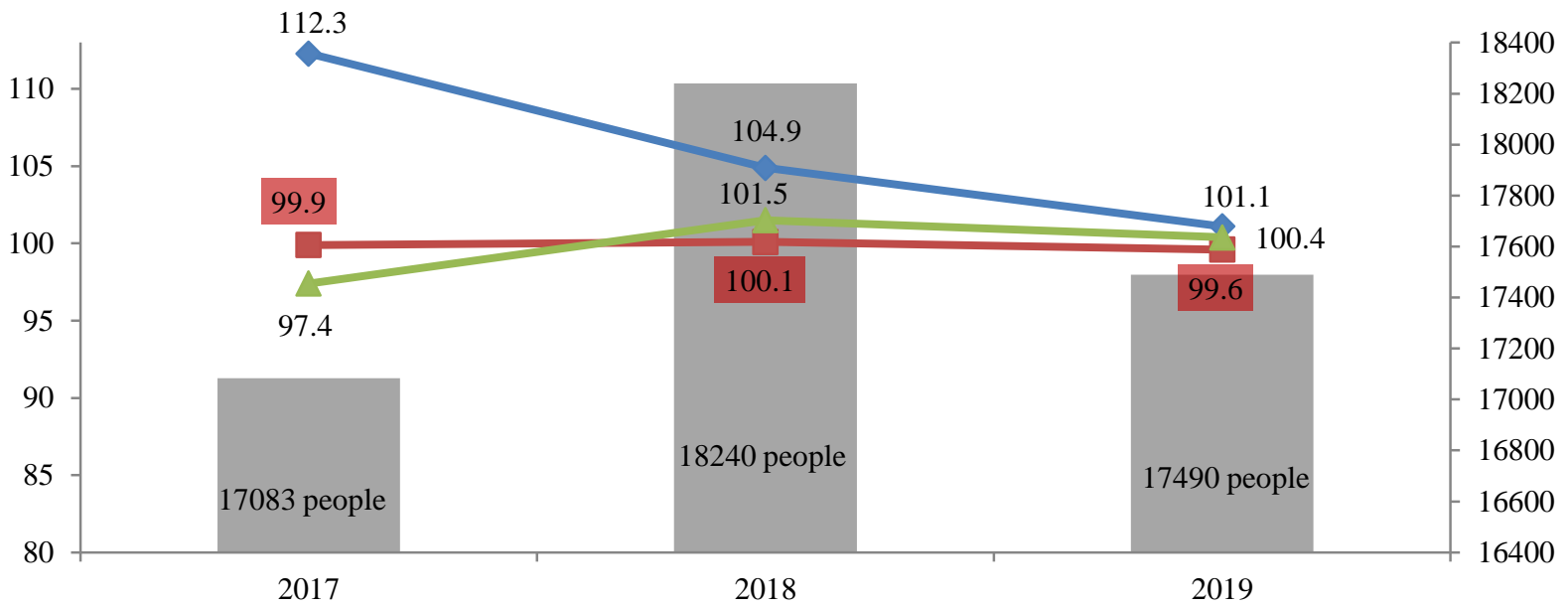

The number of people leaving the region between the ages of 18 and 39 for all migration flows

$\rightarrow$ GRP physical volume index, $\%$

- Volume index of paid services, $\%$

- Retail trade physical turnover index, $\%$

Figure 8. Dynamics of the number of people leaving the region aged 18 to 39 , the index of the physical volume of GRP, the index of the physical volume of paid services, the index of retail trade turnover in the Astrakhan region, 2017-2019

Source: Compiled by the authors

Table 2. The relationship between the influence of the number of people leaving the regions aged 18 to 39 with the main indicators of the socio-economic development of the Astrakhan region

\begin{tabular}{|l|l|c|c|}
\hline \multicolumn{2}{|c|}{ Interrelation of indicators } & $\begin{array}{c}\text { Correlation } \\
\text { Value }\end{array}$ & $\begin{array}{c}\text { Conclusion about the } \\
\text { Level of the Interrelation }\end{array}$ \\
\hline $\begin{array}{l}\text { The number of people leaving the } \\
\text { region between the ages of } 18 \text { and } 39\end{array}$ & $\begin{array}{l}\text { Share of researchers under the age of 39 } \\
\text { in the total number of researchers }\end{array}$ & -0.73 & Strong negative correlation \\
\hline $\begin{array}{l}\text { The number of people leaving the } \\
\text { region between the ages of } 18 \text { and 39 }\end{array}$ & Coefficient of inventive activity & -0.96 & $\begin{array}{c}\text { Very strong negative } \\
\text { correlation }\end{array}$ \\
\hline $\begin{array}{l}\text { The number of people leaving the } \\
\text { region between the ages of } 18 \text { and 39 }\end{array}$ & GRP physical volume index & -0.51 & $\begin{array}{c}\text { Average negative } \\
\text { correlation }\end{array}$ \\
\hline $\begin{array}{l}\text { The number of people leaving the } \\
\text { region between the ages of } 18 \text { and 39 }\end{array}$ & $\begin{array}{l}\text { The ratio of the volume of investments in } \\
\text { fixed assets to GRP }\end{array}$ & -0.97 & $\begin{array}{c}\text { Very strong negative } \\
\text { correlation }\end{array}$ \\
\hline $\begin{array}{l}\text { The number of people leaving the } \\
\text { region between the ages of } 18 \text { and 39 }\end{array}$ & $\begin{array}{l}\text { Index of physical volume of investments } \\
\text { in fixed assets }\end{array}$ & -0.70 & Strong negative correlation \\
\hline $\begin{array}{l}\text { The number of people leaving the } \\
\text { region between the ages of } 18 \text { and 39 } 39\end{array}$ & $\begin{array}{l}\text { Share of products of high-tech and } \\
\text { knowledge-intensive industries in GRP }\end{array}$ & -0.97 & $\begin{array}{c}\text { Very strong negative } \\
\text { correlation }\end{array}$ \\
\hline $\begin{array}{l}\text { The number of people leaving the } \\
\text { region between the ages of } 18 \text { and 39 }\end{array}$ & $\begin{array}{l}\text { Index of physical volume of retail trade } \\
\text { turnover }\end{array}$ & 0.91 & Not available \\
\hline $\begin{array}{l}\text { The number of people leaving the } \\
\text { region between the ages of } 18 \text { and 39 }\end{array}$ & Volume index of paid services & 0.55 & Not available \\
\hline
\end{tabular}

Source: Compiled by the authors 
In addition, the results obtained refuted the assumption of the influence of an increase in the number of people leaving the regions aged 18 to 39 on a decrease in the index of the physical turnover of retail trade and the physical volume of paid services, thus, this relationship is not confirmed.

\section{DISCUSSION}

The study allows one to conclude that the migration of the working-age population has a negative impact on the decline in the main indicators of the socio-economic development of the region. We believe that as a result of the migration outflow of the young population (18-39 years old), the region is losing, first of all, intellectual and creative personnel, which can lead to an aggravation of problems in the labor market. In addition, the negative dynamics of the share of high-tech and science-intensive products in GRP, the coefficient of inventive activity, the share of researchers under the age of 39 in the total number of researchers will negatively affect the economic security of the region (one of the most important indicators is innovation).

\section{CONCLUSION}

The results of the study show that the migration outflow is concentrated mostly among the young population aged 18 to 39 years old, the migration loss of this category of persons has a steady growth trend over a long period of time, which negatively affects the economic development and economic security of the region:

- a decrease in labor potential;

- stagnation of innovative development;

- a decrease in the domestic demand of the population;

- slowdown in economic growth;

- a decrease in natural population growth;

- reduction in investment and entrepreneurial activity.

The identification of migration factors (the outflow of the population from the region at the age of 18 to 39) and their influence on the socioeconomic development and economic security of the region can serve as the basis for further theoretical research.

In practical terms, at the regional level, it is necessary to take comprehensive measures aimed at preventing the migration of the young contingent of the population, since increasing the efficiency of the existing system of managing migration processes will help to ensure the economic security of the region. In this regard, we consider it expedient to develop the digital value of this indicator and introduce it into the fundamental strategic documents on ensuring regional economic security.

\section{AUTHORS' CONTRIBUTIONS}

Elina V. Polyanskaya, Irina I. Chueva, Yury V. Daneykin: general management of the project, analysis and additions to the text of the article. Lilia H. Kolmakova: collection and processing of materials, preparation of the initial version of the text.

\section{REFERENCES}

[1] Decree of the President of the Russian Federation "On the Strategy of Economic Security of the Russian Federation for the Period up to 2030" (May 13, 2017 No. 208). Moscow, Russia, 2017. (In Russ.). Retrieved from: http://kremlin.ru/acts/bank/41921

[2] V. Bovea, L. Elia, "Migration, Diversity, and Economic Growth", World Development, 2017, vol. 89, pp. 227-239. DOI: 10.1016/j.worlddev.2016.08.012

[3] T. Walmsley, A. Aguiar, S.A. Ahmed, "Labour Migration and Economic Growth in East and South-East Asia", World Economy, 2017, vol. 40(1), pp. 116-139. DOI: 10.1111/twec. 12334

[4] S. Sassen, "Regulating Immigration in a Global Age: A New Policy Landscape", The Annals of the American Academy of Political and Social Science, 2017, vol. 570(1), pp. 65-77. DOI: $10.1177 / 000271620057000105$

[5] P. Wiraszka, U. Karpinska, "Economic security as an element of the region's development process on the example of communes of the Świętokrzyskie Voivodship", Baltic Journal of Economic Studies, 2020, vol. 6(3), pp. 67-75. DOI: $10.30525 / 2256-0742 / 2020-6-3-67-75$

[6] L.N. Lipatova, V.N. Gradusova, "Population Migration in the Context of Economic Security and Social Stability", Administrative Consulting, 2020, vol. 1, pp. 56-72. (In Russ.). DOI: 10.22394/1726-1139-2020-1-56-72 
[7] V.A. Prokhoda, "Migration as a threat to security of the accepting society: peculiarities of perception of the native population", National Security / Nota Bene, 2020, vol. 2, pp. 62-82. (In Russ.). DOI: 10.7256/24540668.2020.2.32472

[8] N.A. Pruel, V.N. Gradusova, L.N. Lipatova, "Statistical analysis of human development in modern Russia" ["Statisticheskiy analiz razvitiya chelovecheskogo potentsiala sovremennoy Rossii], Statistics in the context of the formation of the digital economy [Statistika $\mathrm{v}$ usloviyakh formirovaniya tsifrovoy ekonomiki]: materials of the ISPC, Saransk, 2019, pp. 131-139. (In Russ.).

[9] I.P. Tsapenko, "Regionalization of Migration", Outlines of Global Transformations: Politics, Economics, Law, 2017, vol. 10(4), pp. 70-85. (In Russ.). DOI: 10.23932/2542-0240-2017-104-70-85

[10]E.A. Edinak, "The intersectoral employment modeling: input - output approach", In Proceedings of the XV Autumn conference of young scientists in Novosibirsk Akademgorodok "Actual issues of economics and sociology”, 2019, pp. 522-529. (In Russ.).

[11]Decree of the President of the Russian Federation "On the National Security Strategy of the Russian Federation" (July 02, 2021 No. 400). Moscow, Russia, 2021. (In Russ.). Retrieved from
http://publication.pravo.gov.ru/Document/View/ 0001202107030001 ?rangeSize $=1$

[12]Decree of the President of the Russian Federation "On the Concept of the State Migration Policy of the Russian Federation for 2019-2025? (October 31, 2018 No. 622). Moscow, Russia, 2018. (In Russ.). Retrieved from

http://kremlin.ru/events/president/news/58986

[13]A.D. Nasledov, "Mathematical Methods of Psychological Research: Analysis and Interpretation of Data”, St. Petersburg: Rech', 2006. (In Russ.).

[14] "Rating of regions by quality of life in 2020", 2021. (In Russ.). Retrieved from http://vid1.rian.ru/ig/ratings/life_2020.pdf

[15] "Rating of Russian regions by unemployment rate", 2021. (In Russ.). Retrieved from https://ria.ru/20210315/bezrabotitsa1601181760.html

[16] "Labor force, employment and unemployment in Russia - 2020”, 2021. (In Russ.). Retrieved from https://gks.ru/bgd/regl/B20_61/Main.htm

[17] "World Association of Young Scientists", 2005. Retrieved from http://www.unesco.org/new/en/naturalsciences/science-technology/sti-policy/globalfocus/young-scientists/world-association-ofyoung-scientists-ways/ 